\title{
Institutionalization of Public-Private Partnership: Global Experiences and the Basic Outlines of a Proposal for Slovenia
}

\author{
UDK: 35.086(1-7) (497.12)
}

\author{
Mojmir Mrak \\ Ekonomska fakulteta, Univerza v Ljubljani \\ mojmir.mrak@ef.uni-lj.si
}

\begin{abstract}
Experiences show that countries use one of the following three forms for "institutionalisation" of their private-public partnership (PPP) activities: (i) centralised, (ii) decentralised, and (iii) mixed. The article argues that the form of mixed PPP "institutionalisation" would be the most appropriate for Slovenia. The institutional structure would be composed of three institutions: (i) central PPP unit responsible, first, for horizontal coordination of all PPP policies in the country, and second, for implementation of PPP projects in all those areas where sectoral PPP units would not be created, (ii) very limited number of sectoral PPP units (probably 1 to 2) that would be responsible for implementation of PPP projects in their respective sectors, and (iii) advisory board that would advise the central PPP unit in designing the most complex segments of the PPP policies in the country and would provide a platform for professional discussion and for communication with the public at large on a wide variety of PPP issues. In substance terms, the central PPP unit would be responsible directly to the government while in organisational terms, it would be incorporated into the institutional structure of the ministry of finance with the head of the unit being directly responsible to the minister of finance.
\end{abstract}

Key words: private-public partnership, institutionalization,

\section{Introduction}

In Slovenia there has been political agreement in principle for at least five years that it would make sense to attract the private sector to financing and managing large infrastructure projects. There was talk of this in the coalition agreement following the parliamentary elections of 2000, and public-private partnership (PPP) also received an important place in the coalition agreement following the most recent elections in 2004. The economic argument for PPP 


\section{Mojmir Mrak}

\section{Institutionalization of Public-Private Partnership}

was further strengthened in the Strategy for the Development of Slovenia adopted in July 2005.

There are several reasons for increased interest in PPP, the most important of which include:

- Engagement of additional private capital: PPP makes it possible to engage additional private capital and in this way reduce the discrepancy between the needs of the state for investment in infrastructure and the traditional sources of funding available.

- Sharing of risks: PPP facilitates better sharing of risks between the public and private sectors.

- Potentially lower project costs: Because of synergistic effects and innovative approaches by the private sector to planning and carrying out projects, the cost of realizing projects through PPP are often lower than those realized in the traditional manner.

- Potentially faster project development and realization: Countries with an active PPP program are able to considerably shorten the time from conceiving an idea for an individual project to its realization.

Economic policy measures in at least the following three areas are required in order to create political support for the development of PPP in principle:

- Defining content priorities and ensuring broader consensus in countries for the PPP concept: The public sector must prepare a strategy through which the state defines the role of the private sector at the global and sector levels in addition to the role of private investors in financing and/or managing infrastructure. In the Slovenian context it would also make sense for appropriate bodies within the National Assembly to discuss such a strategy. This would represent an opportunity for the PPP concept to receive broader political consensus in Slovenia. This is of no little significance in an environment that has not been well disposed toward private - and especially foreign - investment in areas that have traditionally fallen within the domain of the state.

- Preparation and adoption of the legislative environment: This must clearly define the role of the private sector in financing investment in new facilities as well as renovating existing infrastructure facilities.

- Establishment of institutional support: Experience from other countries clearly indicates that creating effective institutional support is of key importance for initiating and developing the PPP concept in a country. 
The basic aim of this article is to precisely define the issue in the last of the areas named above - i.e. the issue of institutionalizing PPP in a country and on this basis to propose the basic outlines of a solution that appears appropriate for Slovenia in this preliminary phase of analysis.

This article contains two main sections in addition to the Introduction and Conclusion. Section Two presents the concept of institutionalizing PPP itself and three basic models - centralized, decentralized, and mixed - that countries are using today to solve the problem of their institutional organization for PPP. Based on the experience of other countries, Section Three and the Conclusion of this article provide the basic outlines of a proposed model of institutional organization that would best satisfy the needs of Slovenia for effective development of PPP policies and their implementation. It should be emphasized that this is very much a basic outline for a proposed model because a more authoritative proposal would require more thorough analysis in certain other areas. For example, it would make sense to at least create a framework overview of projects that could be realized in the coming years as potential PPP projects.

\section{The Concept of PPP Institutionalization and Various Basic Models'}

The basic aim of this section is to briefly present the experience of certain other countries in institutionalizing the organization of PPP. This experience shows that institutional support or the lack of it is one of the key factors that defines a country's success or failure in establishing an active PPP program. In turn, the degree of success of a country's institutional organization for PPP has largely determined to what extent countries have succeeded in principle in directing political inclination for including the private sector in financing and management of infrastructure into everyday practice.

\subsection{Definition of PPP Institutionalization}

The term "PPP institutionalization" can be understood to mean the formation of a standardized PPP model promoted by a central or regional government and carried out in the form of a broad spectrum of activities at various

1 It should be emphasized that this section of the article is based on written documents on the institutionalization of PPP in certain other countries. A more comprehensive presentation of the issue would necessitate direct contacts being made with the coordinators of PPP policy in individual countries. 


\section{Mojmir Mrak \\ Institutionalization of Public-Private Partnership}

levels of decision-making and in various public sector bodies. Responsibility for the development and promotion of the standardized model is usually assumed by a PPP unit formed especially for this purpose.

The experiences of many developed industrialized countries such as the UK, Ireland, the Netherlands, and Greece, as well as certain "developing economies" such as South Africa or the Philippines, clearly confirms that PPP units have been of key importance for these countries in the successful development of an effective system for including private investment within infrastructure financing. These units have become a key element of professional competence for PPP projects in these countries, and have both enabled PPP projects to start in practice and strengthened private investor confidence. In addition, PPP units often assume the role of the chief promoter of the PPP concept in a country. Not least, PPP units usually become a very important source of technical assistance for public administration employees working with PPP and a nexus in the country for exchanging experience in this area among state officials at various ministries and other bodies.

The first phase in the process of PPP institutionalization in a country is the establishment of a specialized PPP unit or PPP task force within the government. The very founding of a PPP unit can have a positive effect. Namely, it confirms the government's inclination toward the PPP concept, and this is a signal both to potential investors as well as to various levels of public administration that the state is seriously thinking about the inclusion of private capital in financing infrastructure and that it is prepared to invest both funding and human resources into establishing the necessary institutional basis. Basing such a PPP unit in a finance ministry is generally assessed as a clear indication that in the future the government will treat PPP as an important element of the government's regular budgetary and development policy for financing investment and that the key coordinators of economic policy in the country will be closely connected with the operation of the PPP unit.

In the first phase of their operation, PPP units usually focus on identifying projects that can serve as PPP pilot projects. Work on pilot projects creates a basis on which a PPP unit can precisely familiarize itself with all the operational aspects of the PPP project cycle and enables the unit, based on its own experience, to begin preparing good practice manuals for PPP projects. Successfully carrying out pilot projects is a precondition for similar projects to take place significantly more quickly and with fewer problems. The establishment of standardized structures and procedures for individual projects is a key element in the institutionalization of the PPP process and can itself act as a promoter of PPP both among potential investors as well as among government ministries and local communities. Successfully realized pilot projects and 


\section{Mojmir Mrak}

their standardization are incontrovertible evidence that the system is working. The standardization of procedures, preparation of standardized contracts, and publication of examples of good practice and concept documents through which the PPP unit provides guidelines for individual issues relating to private sector inclusion in infrastructure financing are of key importance for strengthening knowledge about PPP in the public sector as a whole. Although each PPP project is different and has its own specific features, standardized documents prepared by the PPP unit can significantly facilitate negotiations between the public and private sector, reduce transaction costs, and ensure some kind of minimum standard with regard to the provisions of contracts.

The PPP unit also usually has an important role in educating and informing the public sector about PPP. This is the most effective manner for institutionally strengthening state administration in this area. Experience has shown that the level of general knowledge about PPP increases over time, although specialized knowledge in this area, such as financial analyses and sharing of risks, remains very limited. The PPP unit must be qualified to actively follow current global trends in this area and to transfer innovations into the home environment in an appropriate manner.

The next area that usually forms part of a PPP unit's role in a country is cooperation with line ministries and local communities in PPP projects proposed by these institutions and for which they propose co-financing from public funds. An effective PPP program demands that a clear and transparent system be established in the country for adopting decisions on PPP projects, in which the PPP unit must play a key role. Only clear rules of play can increase private sector confidence that the costs of preparing tenders are not in vain and will enable various groups included in project preparation to assess what is actually happening with the project.

A lack of confidence or open resistance on the part of various interest groups in projects financed through PPP is one of the significant problems that these projects encounter in nearly all countries. Precisely for this reason, fully informing the public about the usefulness of PPP and establishing dialog with the broadest possible spectrum of groups that have a legitimate interest in these projects is usually the next activity for PPP units. These units are the most professionally qualified to comprehensively present the strengths and weaknesses of country's PPP policy, as well as individual projects to be carried out according to the PPP principle.

Finally, PPP units must be involved in the process of regularly monitoring PPP projects carried out in the country. This is not only necessary to ensure that projects provide value for money for their end users (i.e., the population), but also for supervision of the contractual obligations accepted by 


\section{Mojmir Mrak \\ Institutionalization of Public-Private Partnership}

the public and private sectors in the consultation phase of the project. Regular monitoring of the fulfillment of contractual obligations is also of key importance for the private sector because this strengthens their confidence that the obligations agreed to in the contract will be interpreted according to agreed standards.

\subsection{Models of PPP institutionalization}

Countries' experience in PPP institutionalization shows that three basic models have been used in practice.

The first of these, which is used less often, is the model of strongly centralized PPP institutionalization. This is a model in which the entire institutional organization of the country or region for PPP is focused on one specialized institution. This model is found for example in the province of Ontario, Canada. In 1999 the province created a firm called the Ontario SuperBuild Corporation, the basic purpose of which was to effectively respond to the challenges posed by an infrastructure of insufficient quality that the province faced when entering the new millennium. The purpose of the firm was to coordinate a new, more strategically-oriented process for programming investment. This method was intended to interrupt existing practice in the province by which individual ministries made use of their own capital and also defined their priorities completely independently. Of course, this meant that potential beneficiaries of funds competed and might even receive funds from different ministries. Neither the government nor other institutions at the central level had an overall picture of what was happening with infrastructure investment. In line with the planning process established by the Ontario SuperBuild Corporation, analyzing investment from the viewpoint of the entire country became obligatory. Anyone wanting to compete for public funding was required to obtain permission for their development projects from this firm and a special government committee that was responsible for the strategic assessment of investments and adopting investment plans for the government as a whole.

An example of a country that began its PPP program with a completely different institutional approach, the strongly decentralized PPP institutionalization model, is Portugal. In this country, which was especially active in PPP in two areas - roads and water management - no central unit was established to support and coordinate the preparation and carrying out of PPP projects. This area was more or less completely left up to line ministries and local authorities, which each organized PPP projects in their own way. Here, however, the fact cannot be overlooked that an informal task force was also established 


\section{Mojmir Mrak}

in Portugal that offered potential participants in PPP projects advice on various forms of PPP and on legal and financial problems connected with preparing and carrying out such projects.

By far the most frequently used model of state institutional organization for PPP is the mixed model of PPP institutionalization. This is a model that combines both of the models presented above. In doing so, it attempts to exploit the advantages of both as much as possible and to reduce their weaknesses. The following two (or three) groups of institutions basically comprise this mixed model:

- Central PPP unit: This is a unit that is usually located within a finance ministry whose activities include (i) coordinating and development functions, including standardization of procedures and processes, (ii) educating the private sector about PPP and providing examples of good practice, (iii) informing the public, and (iv) coordinating PPP with various entities that have an interest in PPP.

- Sectoral PPP units: These are units at the level of line ministries whose basic function is the identification and development of projects and all activities connected with selecting private sector partners that the public sector should enter into partnership with.

- Other institutions: In addition to the two groups of institutions mentioned above, which represent the basis of the mixed model of PPP institutionalization, individual countries have either established or promoted the establishment of various other institutions that should have the common goal of contributing to the development of the most effective PPP program. Thus in some countries various advisory bodies have been founded with members representing the business sector and civil society, through the assistance of which these countries wish to promote professional discussion of PPP and to reduce the information deficit regarding the issue of PPP.

Close connection and harmonization between the PPP program, the budget, and the public procurement system is of key importance for an effective PPP system in a country. A PPP program must become a component part of the state's budget planning and implementation and, through these, a fully equal method of financing infrastructure. Because of the specific features that arise in the relationship between the public and private sector, PPP also represents a special challenge related to harmonizing the public procurement rules, in the framework of which competitive dialog (or competitive bidding) is especially important for PPP. This entails the issue of preventing public funds (or taxpayer funds) from being used as a source of possible excess profit for the private sector. 


\section{The Basic Outlines of The Proposed PPP Institutionalization Model in Slovenia}

On the basis of a relatively superficial analysis of experiences in other countries and with an awareness of the current status and needs of Slovenia for PPP, I believe that the most suitable organizational structure of this type for Slovenia would combine the centralized and decentralized models of PPP institutionalization. The basic outlines of the proposed mixed model are based on solutions that proved successful in Ireland and the UK.

\subsection{The basic institutional structure of the proposed model and arguments in favor}

The model basically strives to establish a central PPP unit with a strong coordinating role and a small number of sectoral PPP units focusing on the development and implementation of individual projects, including the overall problem of selecting a private partner. It would make decisions on which line ministries should establish sectoral PPP units, based only on an analysis of potential BOT projects in Slovenia. The PPP projects of ministries where establishing sectoral PPP units could not be justified would be carried out on the basis of a special agreement between that ministry and the central PPP unit. Of course, this means that, in addition to its basic role as a coordinator of PPP policy in the country, part of the central PPP unit's work would involve carrying out PPP projects.

The basic reasons in favor of a combined model are the following:

- Possibility of better coordination: A central PPP unit could play the role of a coordinator in the preparation and implementation of PPP policy. In addition, this is the appropriate institutional environment for putting into practice the principle of "best practice" among individual parts of public administration and sectors.

- Potential for developing a center of excellence: Because of its critical mass of specialized staff, a central PPP unit in principle has a greater possibility of truly becoming a professional center of excellence in PPP for the country. Such a center can ensure quality technical assistance to line ministries and local communities in realizing concrete projects that fall within its responsibilities. 
- Faster implementation of adopted decisions: A central PPP unit can more easily establish the conditions that are necessary for fast and quality implementation of the adopted guidelines for PPP economic policy.

- Possibility of greater consistency of policies among individual sectors: As a central PPP unit must ensure consistency in PPP policy, it is understandable that this body is very suitable for shaping and carrying out all policies of a cross-sectoral nature.

- Adaptation to the needs of various line ministries and local communities: This model is sufficiently flexible with regard to the role that the sectoral ministries and local communities have in the process of implementing PPP. It enables line ministries with a large number of potential PPP projects to focus on preparing and carrying out projects through sectoral PPP units and provides line ministries with a small number of potential PPP projects with access to its staff, which is also highly qualified for directly carrying out projects.

\subsection{Presentation of individual institutions' tasks as part of the proposed model}

The proposed model argues for the formation of three types of institutions: (i) a centralized PPP unit, (ii) a limited number of sectoral PPP units, and (iii) an advisory body for PPP. The remainder of this subsection will present the role of each of these in somewhat greater detail.

- Central PPP unit: This unit, which would be organized within the Ministry of Finance, would have the following tasks:

- Developing policies and procedures as well as preparing good practice manuals that could be used to prepare and carry out PPP projects in all sectors.

- Shaping and maintaining the interests of the private sector in PPP projects. 


\section{Mojmir Mrak \\ Institutionalization of Public-Private Partnership}

- Ensuring the exchange of information about PPP between various parts of public administration and organizing appropriate education for staff in this area.

- Designing and maintaining a database on staff that could contribute in various ways to the successful development of PPP in the country.

- Ensuring assistance to sectoral PPP units, other ministries, and local communities in seeking solutions for how to apply PPP most successfully.

- Establishing and maintaining constructive dialog with key institutions that have an interest in PPP, on economic policies connected with PPP, on the procedures for carrying out these projects, and on both good and bad experiences that other countries have had with PPP.

- Ensuring operative assistance - especially financial and legal - in planning and carrying out PPP projects initiated by line ministries in which sectoral PPP units have not been established.

- Preparing documents for the government on all aspects of PPP that must be dealt with and adopted by the government.

- Supervising and ex-post evaluation of PPP contracts to assess whether the project provides the proper value for money invested.

- Identifying and developing new business opportunities in PPP, including new models and products developed in an international framework.

- Ensuring the necessary conditions to make possible a stable "pipeline" of PPP projects in the country.

- Ensuring regular and effective exchange of opinions with people from sectoral PPP units and people involved with PPP projects at the ministries that do not have these units. If it proves necessary, this exchange of opinions may even be institutionalized in the form of some sort of interdepartmental group of PPP experts.

As already stated, the central PPP unit would conduct activities that are distinctively horizontal in nature because its basic goal would be to carry out the overall government policy on PPP. Of course, this means that in terms of content the central PPP unit actually operates as a "staff service," because it would be directly responsible to the prime minister for its work and also linked to the prime minister's office with regard to status. However, because the role 
of the central PPP unit will be distinctly financially oriented and will require close cooperation with all parties included in the preparation and implementation of investment, it is logical (and this is also the practice of practically all countries with a similar battery of institutions) that it be located at the Ministry of Finance and that its director be directly responsible to the finance minister.

At this time it is too early to speak about how many staff it would make sense to have at the central PPP unit. This depends on many factors, including the extent of horizontal functions that will be assumed by the unit and the extent of projected work that it will actually be carrying out (depending on the number of sectoral PPP units). Nevertheless, if Slovenia intends to seriously enter into the PPP institutionalization, then the central PPP unit will have to take over the key functions in shaping PPP policy; economic, financial, and legal evaluations of projects; and general project management. The staff for some of these activities could be provided from existing staff in the public sector. There also exists specific PPP knowledge required for the work of the central PPP unit that is as yet simply unavailable in Slovenian public administration or is extremely rare. For example, this includes knowledge in project and entrepreneurial financing, contract law, risk assessment, and so on. In the first phase, these problems could be resolved by engaging advisors and perhaps even temporary arrangements with the private sector on the retirement of staff, while in the long-term the unit would have to strive to create its own staff potentials in these areas.

- Sectoral PPP units: These units, which would be established at line ministries that have or will potentially have a sufficient number of PPP projects, would basically have the following tasks:

- Managing processes for identifying PPP projects and their development, including preparing and carrying out the entire procedure for selecting private sector partners. All this activity would be carried out in cooperation with the central PPP unit.

- Organizing and coordinating the necessary technical expertise for projects within the activities of ministries in which a sectoral PPP unit is located.

- Managing dialog with key institutions that have an interest in the project. This activity would also be done in close cooperation with the central PPP unit.

- Designing and maintaining a suitable "pipeline" with projects within the activities of ministries in which a sectoral PPP unit is located. 


\section{Mojmir Mrak}

\section{Institutionalization of Public-Private Partnership}

At present it seems reasonable to consider two sectoral PPP units in Slovenia, at the Ministry of Transport (i.e., projects in transport and communications) and at the Ministry of the Environment and Spatial Planning (i.e., projects for purification facilities and incinerators). The issue of how to support PPP projects that are initiated by local communities needs to be analyzed separately.

Advisory body for PPP: The fact is that the level of familiarity with different forms of PPP in Slovenia remains very low. In addition, until now there have been no serious discussions among the professional community on the strengths and weaknesses of the PPP approach, and of course there is also a lack of contact and dialog with the very different groups of institutions and individuals that could have a special interest in a specific PPP project or in PPP as a whole. If the government wishes to respond to this clear deficiency in a rational manner and thus contribute to objective professional discussion of this issue, then it would make sense to form or promote the formation of a special advisory body for this purpose that could provisionally be called the PPP Advisory Body. Representatives of the public and private sector, advisory organizations, banks, and other businesses with an interest, as well as experts from academic circles, unions and the general public would be invited to become members of the group. This advisory body, which should not be too large, would represent a forum for serious discussion of important content-related issues in the development and operation of PPP, and could also represent a channel for dialog with all those with a legitimate interest in issues in this area.

\section{Conclusion}

The experience of other countries has shown that three basic models of PPP institutionalization are used in practice: strongly centralized, strongly decentralized, and mixed. The great majority of countries use the last model.

It would make most sense for Slovenia to use the mixed model of PPP institutionalization as well. Even though the final decision on the institutional structure could only be adopted on the basis of at least a preliminary record of potential PPP projects (by number and type) in the country, at this time the following structure appears most appropriate:

- A central PPP unit with the central role of developing all horizontal PPP policies and with the accompanying role of carrying out PPP projects in areas for which sectoral PPP units would not be set up;

- A very limited number of sectoral PPP units (1 or 2) with the exclusive task of all-around management of PPP projects in their areas; 


\section{Mojmir Mrak
Institutionalization of Public-Private Partnership}

- An advisory body for PPP that would offer advice on key issues of managing PPP policy in the country and would represent a channel of communication with the public.

The central PPP unit, which ought to be established as soon as possible, will be responsible to the government as a whole with regard to content, and in the organizational sense will be included in the Ministry of Finance, so that its head is directly responsible to the finance minister. The operation of the unit must be closely connected and harmonized with budgetary planning and carrying out investment in infrastructure as well as with the institutions responsible for public procurement in Slovenia.

The conditions required for the central PPP unit to function normally must be ensured. In this relation it is especially important to provide a sufficient number of people capable of carrying out the tasks set. The staff needed to implement specific tasks could be provided from existing staff in state administration, while a solution would have to be sought outside this circle for some other tasks. In the short-term this would also probably involve advisors and the temporary hiring of staff from the private sector.

Mojmir Mrak je redni profesor za področje mednarodnih financ na Ekonomski fakulteti in na Fakulteti za družbene vede Univerze v Ljubljani, poleg tega pa redno predava na magistrskem študiju $v$ Sieni, Italija ter na doktorskem študiju na Dunaju, Avstrija. Je avtor oziroma soavtor številnih člankov in knjig objavljenih doma in v tujini, poleg tega pa je $v$ svoji dosedanji karieri opravljal svetovalne naloge tako za številne mednarodne organizacije, kot npr. OECD, OZN, IBRD, EBRD, IFC in EC, kakor tudi za vlado Republike Slovenije in vlade nekaterih drugih držav. 


\section{Mojmir Mrak \\ Institutionalization of Public-Private Partnership}

\section{Literatura in viri}

- Department of the Environment, Heritage and Local Government (2003). Policy Framework for Public Private Partnership (PPP) in Ireland. Evolution of PP Policy in Ireland. (November 2003). www.environ.ie

- $\quad$ EIB Papers (2005). Innovative Financing of Infrastructure - The Role of Public-Private Partnerships. Infrastructure, Economic Growth, and the Economics of PPPs. (= Volume 10, no. 1 and 2.) www.eib.org/efs

- $\quad$ Office of the First Minister and Deputy First Minister (OFMDFM) (2002). Review of Opportunities for Public Private Partnerships in Northern Ireland. (Consultation document, May 2002)

- $\quad$ PPP in Ireland - An Update. March 2004.

- $\quad$ Thomas, Emma (2002). Institutionalization of Private-Public Partnership (PPP). IP3. www.ip3.org/pub/publication2002_018.htm 


\section{POVZETEK}

\section{Institucionalizacija javno-zasebnega partnerstva: izkušnje v svetu ter osnovne konture predloga za Slovenijo}

Koncept javno-zasebnega partnerstva (JPZ) obsega zelo različne oblike partnerstva med javnim in zasebnim sektorjem. Avtor se $v$ tem prispevku osredotoča samo na tisto obliko partnerstva, ki vključuje investicije $v$ nove in $v$ obnovo obstoječih objektov na področjih gospodarske in socialne infrastrukture. Izhodišče za obravnavo so izkušnje $v$ svetu, na podlagi katerih predlaga osnovne konture predloga za Slovenijo. Poleg Uvoda in Zaključka sestavljata prispevek še dve osnovni poglavji. Drugo poglavje je tako namenjeno predstavitvi samega koncepta "institucionalizacije " JZP ter treh osnovnih modelov, to je centraliziranega, decentraliziranega in kombiniranega, s katerimi države danes rešujejo problem svoje institucionalne organiziranosti za JZP. Izhajajoč iz izkušenj drugih držav, pa tretje in ključno poglavje prispevka podaja osnovne konture predloga modela institucionalne organiziranosti, ki bi na kar najboljši način zadovoljeval potrebe Slovenije za učinkovit razvoj politik JZP in njihovo implementacijo. Poudariti velja, da gre resnično za osnovne konture predlaganega modela, saj bi bila za bolj avtoritativen predlog potrebna bolj poglobljena analiza na nekaterih drugih področjih.

$\checkmark$ Sloveniji že vsaj pet let obstaja načelno politično soglasje o tem, da bi bilo $v$ financiranje in upravljanje velikih infrastrukturnih projektov smiselno pritegniti zasebni sektor. Avtor navaja 4 najpomembnejše razloge za povečan interes za JZP in sicer: angažiranje dodatnega privatnega kapitala, delitev tveganj, potencialno nižji stroški projekta ter potencialno hitrejši razvoj in realizacija projekta, saj države $z$ aktivnim programom JZP uspevajo znatno skrajšati čas od nastanka ideje za posamezni projekt do njegove realizacije.

Da bi bilo načelno politično podporo razvoju JZP mogoče operacionalizirati, so nujno potrebni ukrepi ekonomske politike vsaj na naslednjih treh področjih: opredelitev vsebinskih prioritet in zagotovitev širšega konsenza $v$ državi za koncept JZP, priprava in sprejem zakonodajnega okvira ter vzpostavitev institucionalne podpore. Avtor se $v$ nadaljevanju članka osredotoča predvsem na slednje področje, saj po njegovem mnenju izkušnje drugih držav kažejo, da je prav institucionalna podpora oziroma pomanjkanje le-te eden od ključnih dejavnikov, ki opredeljuje (ne)uspešnost države pri vzpostavljanju aktivnega programa JZP. 


\section{Mojmir Mrak}

\section{Institutionalization of Public-Private Partnership}

Izkušnje držav kažejo, da se v praksi uporabljajo trije osnovni modeli "institucionalizacije " JZP - močno centralizirani, močno decentralizirani in mešani. Daleč največje število držav uporablja slednjega. Avtor predlaga, da bi bilo tudi za Slovenijo najbolj smiselno, da se odloči za mešan model "institucionalizacije " JZP, čeprav bi dokončna odločitev o institucionalni strukturi veljalo sprejeti šele na osnovi vsaj preliminarne evidence potencialnih JZP projektov (po številu in tipu) $v$ državi 